\title{
Pragmatism attacking Christianity as weakness - Methodologies of targeting
}

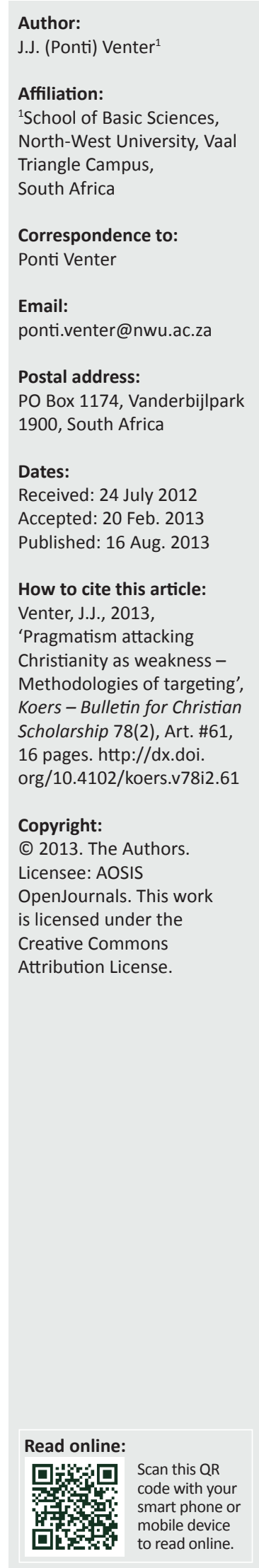

The central argument is that methods are designed with aims in mind, and are determined by one's worldview and/or ontology and/or philosophical anthropology and/or views of scholarship. It is possible, and here shown by analysis of the methodology of William James, that obsession with a cause, driven by the elitist belief that my cause is for everybody's advantage, can take an ideological format (a formalistic ideology), in which case it would show tendencies to polarise. In the case of James the scientistic methodology takes as primary target Christianity's meekness and kindness as humanitarianly ineffective. But James suffers from the problem of intellectual solipsism: reading Christianity via abstract rationalist theology.

Pragmatisme se aanval op Christenheid - Teikeningsmetodologieë. Die sentrale argument is dat metodes ontwerp word met doeleindes in gedagte en bepaal word deur 'n persoon se werklikheidsvisie en/of ontologie en/of filosofiese antropologie en/of sienings van wetenskap. Dit is moontlik dat 'n obsessie met 'n saak, gedryf deur die elitistiese oortuiging dat my saak tot almal se voordeel is, 'n ideologiese formaat kan aanneem ('n formalistiese ideologie). In so 'n geval toon dit neigings om te polariseer. Ter illustrasie hiervan, is William James se metodologie in hierdie artikel geanaliseer. In James se geval neem die sciëntistiese metodologie die Christendom se sagmoedigheid en welwillendheid as primêre teiken om aan te toon dat dit op humanitêre vlak oneffektief is. James ly egter aan die probleem van intellektuele solipsisme: hy lees die Christendom via abstrakte, rasionalistiese teologie.

\section{An impractical God and his weak followers}

You are not like us; therefore you are unacceptable. You serve different gods, other gods; the wrong ones. You have strange faces; the image of a very strange god, who wants you to love your enemy. This is impractical, even dangerous. But: we can show you a method to become like us. These may be the imaginary words of a Modern secularly religious invitation to orthodoxly religious people.

Some people appear to be perpetual xenoi in the world; amongst others serious Christians. What's wrong with them? How can they become worldly and be at-home-in-the-world? Can we show them the way or method to make them skilled in our ways? Can we make them understand that they have chosen the wrong way?

Hasn't Modernity itself alienated the subject from its environment? Made it a stranger? Hasn't the Kantian an sich [per se] really become but a 'Ding' [thing]? Isn't there truth in the Neo-Marxist idea of the reification of all - except certain egos?

The 'strangers' - are they real co-subjects that make a valuable contribution to the humankind's fate? This question is at the centre of this article. William James appears to argue that Christianity is other-worldly. It does not really touch the mud and gore of everyday life. It is hanging in the ideaclouds and never becomes true in our world. This publication is part of a methodologically focused series, via analytical exegesis of texts. James's method of attack will be my main focus; alternative ways of looking at Christianity will also be considered at specific points.

\section{Method, institutional power and modernity}

In the history of Western thought since Hellenistic Scepticism, one power struggle entrenched itself in scholarly methodology: that between church and state. The conflict between church and state exacerbated the tensions between religion and science, or faith and reason, for religion and faith was associated with 'church' whilst 'science' and 'reason' became connected with state. Yet neither of these conceptual associations implied any necessary connections. During the Renaissance this struggle reached breaking point; the state emerged victorious. What kind of a state? And how might this be related to scholarly method? 


\section{The straight jacket of method}

From the point of view of methods developed for targeting the Christian xenoi, there are two kinds:

- those that focus on the (different) weaknesses of supposedly 'authentic' Christianity to cope with the issues of the day, for example Machiavelli and William James

- those that put the knife into the deviations, the evils and the crimes committed by Christians in the name of Christ (for example Hobbes and Voltaire).

Christian weaklings? Heads in the clouds, feet nowhere near the ground! Thus sayeth William James. Yet when we read James, his polar approach was that of a propagandist - he propagates a view of religion and shows Christianity to be no-good for it does not fit into his mould. His style of writing therefore deviates from the standard academic writing of his time (for example that of his close friend, Peirce). In a fairly popular style he seems to tell us what to think by teaching us how to think.

Heidegger was struggling with the issue of method all through his career. He called 'method' the shackles of Modernity. Method, for him - as a late-Romantic mystic was taking a road to where one already is. This is reminiscent of Augustine's Noli foras ire. In te ipsum redi. In interiore hominis habitat veritas [Do not go outside. Go back into yourself. Truth dwells in the inner person]. The real method, argued Heidegger, had to be self-delivery to the logos - the original word that was the house of being (cf. Venter 1995:190ff).

He had a good understanding of the making of Modernity. Since Bacon, Galileo and Descartes, over Locke, Vico, Turgot and Kant, then Comte, Mill, Dilthey and Marx, up to Husserl (at least), the struggle was not only for a good scholarly method but also about a new one. It makes no sense to propagate a new method if one cannot also claim that it is better in reaching the required scholarly aims than all the previous ones. James claimed a peculiarity of method, which is an improvement on the existing method and at least transcending weaknesses of religion.

\section{Faddism and novelty}

Pragmatism claimed a special identity given the particular character of its - all too ancient - method. Is it new or is it old? The struggle for the new in Modernity has its roots in the Renaissance, when Classicism - recovering the 'old' - was the basis of the 'new'. Modernity could not divorce itself from the Medieval idea of the authority of the old; yet simultaneously it remained in revolutionary mood, attempting clear breaks with the past. The difficulty was: how to claim an original contribution that would stand out in the great stream of history? Humanism wanted human beings to be creative in the same sense as God-creating - from beyond-inside history.

Too much innovation becomes faddist (a trend amongst socalled 'Post-Modernists'). Too strong a rejection of all the previous in order to highlight one's (possibly not so very new) innovations, leads to scepticism and relativism, which calls for an authoritative historical foundation: the Ancients had already seen ... what I see ... Historical stances show a dialectic of absolutisms and relativisms.

A Hellenistic Sceptic witticism has it that amongst philosophers if one milks a goat the other will hold a sieve underneath. Every philosopher holds that only he or she has the truth and all the others are wrong. Modernity could not avoid the same fate, at least according to the later 20th century thinker, Feyerabend (1975):

The idea of a method that contains firm, unchanging, and absolutely binding principles for conducting the business of science meets considerable difficulty when confronted with the results of historical research. We find, then, that there is not a single rule, however plausible, and however firmly grounded in epistemology, that is not violated at some time or other. It becomes evident that such violations are not accidental events, they are not results of insufficient knowledge or of inattention that might be avoided. On the contrary, we see that they are necessary for progress. Indeed, one of the most striking features of recent discussions in the history and philosophy of science, is the realisation that events and developments ... occurred only because some thinkers either decided not to be bound by certain obvious methodological rules, or because they unwittingly broke them. This liberal practice, I repeat is not just a fact of the history of science. It is both reasonable and absolutely necessary for the growth of knowledge. (p. 23)

Experts and laymen, professionals and dilettanti, truth freaks and liars - they all are invited to participate in the contest and to make their contribution to the enrichment of our culture. The task of the scientist is, however, no longer to 'search for the truth' or 'praise god' or to 'systematise observations', or 'to improve predictions'. These are but side-effects of an activity to which his attention is now mainly directed and which is to make the weaker case the stronger as the Sophists said, and thereby to sustain the motion of the whole. (Feyerabend 1975:30)

Feyerabend (1975) sees the dialectic, but does not solve it. His reading matter included Lenin, Hegel, Mill, Kropotkin, Strindberg, Cohn-Bendit, Dadaism and other revolutionaries. He called himself an anarchist. However, he undergirds his work by inserting himself surreptitiously in the older methodological tradition (as Heidegger, for all his attempts to approach a poetic style, also did). Feyerabend's book entitled Against method (1975) shows a clear plan to elucidate (if not demonstrate) his viewpoint that theories and rules have really never mattered that much in science. Yet Pragmatism, Feyerabend's near predecessor, as will be shown below, identifies itself solely by the peculiarity of its method (and thus the rules of thumb accompanying such a method). Feyerabend does see the important discontinuities clearly; the problem is that he suppresses the continuities that are present (even shining through in his own work). It could be exactly the limitations of being-human in thinking (such as readability and comprehensibility), that enforces some continuities.

\section{Science and person}

Feyerabend (1975:25) saw that methods contained hidden strategies (such strategies often being not-so-nice) - a well- 
trained rationalist was a 'brainwashed' person who did not even realise that the appeal to reason was 'a political manoeuvre' . Though quite strongly stated, the issue of power - usually connected with reason and with secular power structures, such as the state in its struggle against the church, has always been part of rationalism. In the history of the idea of 'rationality,' - it being a totalitarian conception rather than a clearly definable concept - the social power structures in the environment (though surely not the only components) do shine through: Medieval rationality proposed a purely logical search for God; middle Modernity a peaceful morality favouring humankind as summit of reality; since the 19th century rationality became competition for own advantage; in the area of Pragmatism it is focused into goal-directed mastery and self- or social advantaging (cf. further Venter 2012a, 2012b).

Galileo Galilei, Feyerabend says, had been a real chancer and an intellectual thief (1975:99ff) - and in spite of his pretended anarchism, he does provide some evidence for this.

Feyerabend (1975) did see the reduction of the scientific person: being squashed into the narrow borders of beinga-scientist, even a special scientist, working under the strict rules of methodological purification:

A person's religion, for example, or his metaphysics, or his sense of humour (his natural sense of humour and not the inbred and always rather nasty kind of jocularity one finds in specialised professions) must not have the slightest connection with his scientific activity. His imagination is restrained, and even his language ceases to be his own. This is again reflected in the nature of scientific 'facts' which are being experienced as being independent of opinion, belief, and cultural background. (p. 19)

He did also sense the deep tensions brought about by philosophical bias, religion, power struggles and so forth. He did not attempt to reconcile them: he followed a dialectical revolutionary anarchist approach. And yet not: the dialectical tensions have to lead somewhere: one has to increase knowledge and keep the cultural snowball rolling. Outcomes are important - yet undecidable.

However, his anarchism did not come out victorious: something more basic to Western thought won the day, namely technical specialism (a kind of method-ism). This was a return to early Modernity in an Irrationalist form called Pragmatism. Machiavelli, to be discussed in another article, and Hobbes, do show the early Modern tendencies recovered in Pragmatism, especially the naturalistic limiting of expected outcomes. Natural(istic) outcomes are important; the manner of reaching them effectively even more. The main issue here was: Is efficiency subject to norms or is any approach that 'works' acceptable?

\section{Jamesian pragmatism}

The question just posed surfaced acutely with the advent of Pragmatism towards the 1870s. It was at that stage that Peirce and James began to formulate their own format of Irrationalism, called Pragmatism. Only decades before
Auguste Comte had begun to move away from strict scientism to a kind of sentimentalist moralistic mastery of the natural world.

\section{Action and its meaning}

Since the 18th century human life - had been seen - at least by intellectuals - as (ideally) one of activism, the French Revolution and the Bolschevik revolution being summits of such activity. But the West was also shocked by yet more brutalities committed in the name of justice, as well as the swell of reactionary activism in Metternich, Bismarck, the Napoleontic wars and more than one Napoleon.

Modern activism has its roots in the faith in progress. This was a transformation, by and large, of the 12th - 13th century historical group mysticism of the Joachimists. Christian mysticism usually has been and still is a mystical journey of the individual soul. Joachim of Fiore (11th - 12th century) transformed the Augustinian individual mystical road - sense, reason, intuition - into a group-elitist historically progressive one: old Testament Jewish sensuality moving up to New Testament Christian rationality summiting in a New Jerusalemist intellectually-intuitive mysticism. When by the mid-13th century there had been no progress towards a popeless, churchless New Jerusalem (as predicted), the Joachimists tried to twist the hand of God, using violence to promote progress. Mysticism always had an elitist trait, but a lonely mystic-in-ecstacy was barely a social danger. The group mysticism of the Joachimists introduced group superiority and thus rationalised manipulations from 'above'.

One has but to read Lessing, or Mozart's librettos, to see a secularist recovery of Joachimistic philosophy in Modernity. For so many centuries Europe had been struggling to throw of the yoke of the nobility acting in cahoots with an established church. When the faith in progress and the human kingdom of God did not produce progress, Modernity attempted to twist the hand of historical human reality, by revolution and violence. Given secularism, Christianity became a serious culprit. Ego's self-reflection delivered xenoi as things-in-themselves useful for, but not really fellow subjects of the Modern agenda ${ }^{1}$.

Since Machiavelli and Hobbes, Rationalism had a clear agenda: human well-being, material welfare, peace and stability. Activism had taken hold of the European mind (note the utopian attempts of the 19th century). But how to make sense of action? The Humanist agenda had to be reached by activism - war, competition, exploitation, et cetera being a necessary part of it. Voltaire, in Candide and his Dictionnaire philosophique portative (1765, s.v. bien) struggled with this Leibnizian idea that evil has to be an essential part of (attaining) the good. Marcuse says: ‘human life is a life worth living (cf. Marcuse

1.I am using the term 'agenda' to indicate a broad intention that was in discussion since the Renaissance thinker, Bacon, and explicitly in Descartes. The very idea of the Renaissance the of Humanism was to work rationally, and later irrationally, for health and peace. The outcomes were mostly opposite. Latour (1993) calls these broad intentions, together with its conceptualisation, the 'constitution' of Modernity. The term agenda covers only one aspect of this - the 'agenda'. Most of Modern intention, culture was aimed at fulfilling this agenda. 
1966:x)'. Why would human life have any worth at all? How to make sense of participating in this activism?

Making sense of action, or rather human-centered activism, was part of the issue in Nietzsche's strange form of 'nihilism'; of Marx's and Engels's revolutionary doctrines; even more so in Blondel's L'action. Auguste Comte, who had rejected all ultimate 'why's' in favour of laws expressing observable regularities, realised that Positivistic natural science in itself made no sense. Having been part of Saint-Simon's activism in favour of the lower classes, he surreptitiously reinserted an ultimate 'why': Humanity as God, thus falling back on an ontology of human advantage (cf. Venter 2012b:ch. 6).

Interestingly William James counted Blondel - a modernised Roman Catholic transcendentalist - amongst the 'fellow' Pragmatists of his days (James 1913:viii). They shared a strong interest in human action but surely found different meanings for it. Blondel's argument was that of a transcendental meaning; an explicit meeting with the grace of God (Kierkegaard?) at the horizon of experience. James, surely, would call this taking a legitimate moral holiday. He took the opposite route: empiricism rather than transcendentalism. Yet the search for empirical facts, as Comte and others had already seen, provided no internal meaningfulness.

James hooked onto this directionlessness, pretending not to have any doctrine at all, but only searching for the empirical effects of our ideas. One had but to relate fact to fact in a consistent way. But why? What for? What 'sense' would this operation have?

Being at some distance from the 'Christianity' of his days, he must have had hidden Humanistic norms such as human advantage. His search - given his examples - was not simply for effects but for those effects that Feyerabend later also searched for: 'good' ones! And 'goodness' for him did not lie in the transcendental (religious) direction without (Pragmatist) ado. Groothuis (2013), following Bertrand Russell, argues critically that to execute James's idea of truth, one needs to know in advance what 'goodness' means and also whether a specific idea will have such effects. Thus one needs to have a supreme truth that gives the criteria of goodness and needs to assume the truth of presupposed logico-causal relationships that will make any other idea conform to the supreme truth.

James curiously avoids talking about the great secular revolutionary events of Modernity (embarrassing?) - the bloodshed for the sake of good effects - and focused on the relationship between ideas and individual situations. Here one could more easily show the 'Rationalists' at fault (and among these put the Christian weaklings near the 'bull's eye'). He must have read Modernity solely via thinkers like Hegel, not to have realised the anti-Christian secularism in Rationalism itself.

Focusing on James's famous book, Pragmatism (2013), I shall try to show how such hidden presuppositions determined a skewed presentation of the world of thought and Christianity's place in it.

\section{Personal temperament and human action: The problem of comparison}

In his famous series of lectures delivered in 1907 in Boston and New York, published under the title, Pragmatism: a new name for some old ways of thinking, James distinguished two temperaments in philosophy: the tender-minded and the toughminded (James 1913:12). He summarised the characteristics of the two temperaments in a table (see Table 1).

To distinguish intentionally is a question of valid comparison. At the basis of all scientific analysis lies the issue of comparison; an intentionally planned process of distinction. This is probably the most complex part of scholarly analysis.

Tabling surely is a form of comparison, but not the other way round: comparison is not simply a listing of or tabling of similarities and differences. For tabling hides the deeper issues regarding valid comparison. Normatively stated, it should not be limited to listing, since:

- a comparison has an aim

- the aim (subjective side) and the nature of the compared (objective side) ought to meet

- these two determine the points of comparison.

Normally a comparison aims at showing that either similarities or differences dominate; it wants to conclude to a familial relationship or a non-familial relationship. (Of course there may be undecidables.) Once such a relationship has been established this can be used for further purposeful argument. More than simply tabling similarities and differences, comparison is (or could be) related to 'equation' in algebra and/or arithmetic: $\mathrm{a}+\mathrm{b}-21=\mathrm{c}-\mathrm{a}$.

This says (and note it is a norm for the process of numerical comparing):

If you have an amount $\mathrm{a}$, and you add an amount $\mathrm{b}$, and you subtract an amount of 21 ,

then the sum ought to be equal to an amount $\mathrm{c}$, from which one subtracts the amount a.

From this it is possible (given enough information in the equation) to deduce in terms of the oughts for deduction: the value (amount or quantity) of $\mathrm{c}$, or of b, or of a.

What value(s) do we deduce? In the present case that or those that serve James's intentions. The objects have been chosen to suit the aim. In the majority of cases the compared and determined values will not be numerical. One has to note

TABLE 1: Summary of characteristics.

\begin{tabular}{llll}
\hline $\mathbf{N r}$ & Tender-minded & $\mathrm{Nr}$ & Tough-minded \\
\hline 1 & Rationalistic (going by principles) & $\mathrm{A}$ & Empiricist (going by facts) \\
2 & Intellectualistic & $\mathrm{B}$ & Sensationalistic \\
3 & Idealistic & $\mathrm{C}$ & Materialistic \\
4 & Optimistic & $\mathrm{D}$ & Pessimistic \\
5 & Religious & $\mathrm{E}$ & Irreligious \\
6 & Free-willest & $\mathrm{F}$ & Fatalistic \\
7 & Monistic & $\mathrm{G}$ & Pluralistic \\
8 & Dogmatical & $\mathrm{H}$ & Sceptical \\
\hline
\end{tabular}


that an equation is a deductive form of argument. What comes out in the conclusion has to be in the premises. Comparisons, being analogies of equations, have to show the outcomevalues as derived from the elements compared. The values we end up with ought implicitly be part of the argument, already from the point of departure.

This poses a danger: one can select one's points of departure so that a required conclusion simply has to follow; or one can purposefully combine them with an implicit agenda. Or: one can read - consciously or unconsciously - meanings into the elements compared to suit one's agenda; this happens when the objects used for comparison - the exemplars taken - have been selected to suit one's case. Popper's criterion of good scholarly work, namely falsifiability, is actually an instruction to search for exemplars that will not suit, but severely test one's case (cf. Popper 1969:33ff). It is important to make our mistakes as fast as possible, for this is 'experience' - quoting Wilde and Wheeler to this effect (on the 5th title page).

The term 'value' has its origin in economic thought: the valuation of a product in a situation of exchange. It is thus subjectivist in origin: how the seller assesses his or her product; how the buyer assesses the same product, and the final agreement found between the two subjects. The value will be expressed in numerical terms whether the exchange takes place in monetary terms or in terms of bartering products for products (cf. Venter 1994).

In the environment of ideology the values would become the justifications of the means and will probably not be numerical. But cultural practice often provides the aims and the values: presently we are living in an economistic environment where comparisons tend to deliver economic values in terms of numbers. Why else do we currently have the tendency for numerical values to dominate or replace all other 'importants'?

In comparing, one has to note especially critical differences or critical similarities. Points of comparison are usually not of equal importance. Present-day transdisciplinary methodologies may easily become reductionist since they may too easily be insensitive to critical differences. When one compares chemical reactions involving the same original elements, it makes for a critical difference whether the elements meet one another on top of a rock face or in a living organism. The very same elements combine in very peculiar ways within a biochemical context compared to an inorganic context. Fully materialist reductionists may attempt to reduce biochemical reactions to inorganic processes; bio-spiritualists may argue the other way round. In economics the components in an equation are often weighted before being included (or not), for example the Gross National Product equation (like horses carrying different 'stone' in handicapped races).

Ideology often blinds the social and political scientist to such critical differences or similarities, or may shift the comparison to an alleged critical difference or similarity in the object itself. This is the reason why Marxists call capitalists 'vulgar' materialists
- these latter are supposedly unable to see the critical difference that 'life' (as contradictory progressive power) makes to history. From the side of capitalism the response will be that individual 'freedom' is more critical to social wellfare and well-being than imposed 'equality'.

All these are quite important in reading James's table (see Table 1). The evaluative, judgemental character of the oppositions is suppressed in the table, but the discourse carries emotive suggestions: surely one would rather be counted amongst the tough-minded than amongst the tender? Even though the oppositions as given are quite prejudiced and inaccurate, we can leave the details aside in order to look at the broader tendencies and their historical roots. Feyerabend sustained the tensions by welcoming - with their personal temperaments - everybody into the fold. Jamesian Pragmatism attempted to solve the tension, very clearly defined in terms of an oppositional hierarchy, by pretending that Pragmatism was 'only' a method; not a doctrine. It is but the passage in a house where everybody can have his or her own room.

Pragmatism is inside the table and yet not, since it sets itself up as mediator, very much like Modernity's elitist ambiguity of being both inside history and in an Archimedean point above history. Unsurprisingly Pragmatism turns out to have all the characteristics of the tough-minded temperament; it is not only the passage but also occupies all the rooms on the right-hand side of the passage. Thus if one wants to enter a room on the left for some 'tender-minded' property, one has to go through the security system of the tough-minded (passage) and be cleansed of all that is 'inefficient' and 'ineffective'. Note, Pragmatism occupies the passage, thus ensuring it is the mediator, the reconciler between the rooms on the left and on the right; it actually is the mediator-forothers and the mediator-for-itself.

Methodological 'purification' is a kind of Modern Platonism developed by Bacon in the Renaissance, radicalised by Descartes, Locke, Hume and Kant; and still present in a Rationalist format in Husserl. James continued the tradition not only from a Lockean perspective, but also from an Irrationalistic perspective. His methodological purification cleanses all of one's religion, one's principles and the avenues of 'free will' - it is a rite of passage into philosophical adulthood.

James was still in the continuation of the emancipatory project of Modernity - old-fashioned but somewhat more abstract: what formerly had been the struggle between church and state here became a serious philosophical opposition. There was a shift from the institutional level (church - already disempowered) to the level of ideas. Ideas have legs but they need good methodical shoes to ensure that they do not drag their feet. Table 1 does in fact not allow any space for 'Christian' ideas as such; Christianity is simply sublimated into the broad spectrum of 'Rationalism' (and as stated above, secularism was the overwhelmingly dominant approach in Rationalism). Religion had its place usually as 
part of emotional pietism (allowing for exceptions such as Kant and Hegel).

In fact, the doctrine of a helpless and ineffective Christianity has utopian roots: one finds it in Hobbes but especially amongst 19th century utopians such as William Godwin, who strongly believed that the Christian idea of voluntary care had not been effective for 19 centuries; the only answer was imposition of sharing by the state. James was more of an individualist, but his colleagues such as Dewey (and later Rorty) were nearer to socialism.

When one approaches foundational issues, the philosopher has to take a stance and rational arguments for one's beliefs are thinning out. James's arguments sound like elitist impositions rather than being convincing (as we shall see later). Purification for the sake of tough-mindedness: is this not enforced scepticism or relativism? And is the purification itself then really only a form, a method; really no dogma at all?

\section{Formalistic ideological purification}

We supposedly live in non-ideological times. But have we actually reached an era of non-ideology?

Taking Goudzwaard's (1981:ch. 1-2) conception of ideology a little bit further, one has to note that ideologies:

- are obsessed with results and outcomes, for they (supposedly) struggle for everybody's cause

- are produced in studies behind the desks of intellectual elites (and in this sense they are near family of the utopians)

- have difficulty in leaving the 'other's' religion intact, for they want the 'cause' to over-rule all norms for means and ends; their cause mostly being of a naturalistic welfare nature

- tend to polarise, setting up an image of the unbeliever in their cause as inimical, as an enemy of human welfare, freedom, equality, justice (mostly conceived of in' naturalistic terms), which justifies a measure of coercion or force (or all too often mass violence).

Ex post facto it is not Feyerabend's 'anything goes' attitude that won the day; it is the Neo-Pragmatist paradigm quarantine that has taken hold. 'Success' is measured by 'excellence in' ... 'Excellence' is here all too often understood as quantity of output.

In order to sustain the image of 'quality' in a situation of immense outputs and mass institutions, the very strict rules of method set by a paradigm are enforced. Assessing of articles and grading of student research assignments have become template application. Remain inside the paradigm and follow the form - a double group solipsism. This is Neo-Pragmatist methodological purification - academic activism, the sense of which remains unclear. Everybody pays lip service at the altar of academic freedom; the sacrificial lambs having been devoured by Pragmatism's Hophnis and Phineases.

Apparently, James's supposed methodological purification has been victorious:
- 'no' dogma, only method

- 'no' theoretical content, only instrumental content

- 'no' content, only formal procedure.

But are we not in danger of an end-justifies-the-means position when enclosed in this kind of formalism? As 'revolutionary anarchist' Feyerabend warned: when 'events, not necessarily arguments ... cause us to adopt new standards', those adhering to the status quo will be forced 'to provide, not just counter-arguments, but also contrary causes' and adding: 'Virtue without terror is ineffective, says Robespierre' (Feyerabend 1975:25). Feyerabend - again overstating his case - yet struggled to make sense of the whole intellectual enterprise, setting output-criteria like, 'progress', 'advance', 'improvement', 'increasing knowledge', 'keeping culture in motion', et cetera, which he then immediately tried to retract. The problem was that even though he opted for Dadaism for a Dadaist would not hurt a fly, much less a human being (p. 21, footnote 11) - he knew quite well that B. Shaw wrote (Feyerabend 1975):

A generation that had the courage to get rid of God, to crush the state and the church, and to overthrow society and morality, still bowed before Science. And in Science, where freedom ought to reign, the order of the day was 'belief in the authorities or off with your head. (p. 21, footnote 10)

A Dadaist would not hurt a fly, but how many scientists are Dadaists? They may not be hurting any flies, yet may hurt many Dadaists! How many do believe in nothing at all, if not even Feyerabend could succeed in believing in nothing at all? Is Kuhn's Pragmatistic paradigmatic solipsism that makes the scientist unaccountable beyond the circle of his paradigm friends (cf. Kuhn 1975:18-20) not an example of Shaw's serious warning against scientism, howsoever we may distance ourselves from his style?

Feyerabend (1975:15) criticises the 'deterioration of language that follows any increase of professionalism'. Kuhn defended exactly this esotericism of the 'professional scientist'. Professional scholars surely, Ibelieve, need technical language in order to stabilise their work. One should, however, reject the elitism implied in the esotericism that had its extremes in the attempts at imposing artificial scientific languages such as that of the Wiener Kreis (cf. Carnap 1932) and still makes it difficult to see the real sense of a scientist's work. Whether one opts for a dialectically polar logic, a formalistic one, or an intuitionistic one - the remnants of initiation type training has outlived Pythagoras for 2000 years. James (and Marcuse) tried to bridge such gaps, but as elitists reaching out.

Right now, the scientists and their technological associates are active political manipulators of government, for tendering and spending billions to have a telescope in the Karoo for scientists to see the first seconds of creation (as an astrophysicist claimed in a TV news bulletin), expressing a superstitious belief in science. Also for building a number of ('very safe') nuclear power stations, whilst a vast formerly fertile area on the Witwatersrand has already been polluted and made dangerous for human use by the uranium being mined together with gold. The mines have become 
untouchable since the National Party government had, and the ANC still has, an interest in selling uranium. Dadaism is no match for a tough-minded methodology.

Methods are plans and plans are aimed at specific outputs. Pragmatism is quite near capitalism, asking for naturalistic outputs; games more than bread. The outcomes are the most important content providers for any method; even for a Dadaist strategy. It is methodo-ideology, inimical especially to Christian religious norms.

\section{Religion versus science}

James tackles his issue - apparently the reconciling of the tensions of Modern thought (cf. James 1913:13-14) - from the point of view of religion versus science. This is important, for it surely was not the only possible starting point that his own table of oppositions (cf. Table 1 above) suggested; that is if one did want to focus on oppositions. The critical difference between the tender-minded and the tough-minded proves to be religion versus empirical science. And of course Pragmatism is supposed to be the mediator - yet tough-minded. This suggests an ideological game:

- He could have taken at least seven other direct oppositions as starting point: 1 vs a, 2 vs b, 3 vs c, 4 vs d, 6 vs f, 7 vs g, 8 $v s h$. Yet his first approach is from the angle of an indirect opposition: 5 vs a (religion versus empiricism).

- He could have used at least 63 other indirect oppositions, yet he begins with a specific 'indirect' one: religion versus empirical knowledge, without explaining his choice.

Certain 'oppositions' have been ingrained into the Western way of looking at reality. This specific opposition has vaguely been present in Plato but became very acute during the tense years of Early Christianity. Feyerabend (1975) noted many of the deficiencies present in the mind of James, as seen in the following quote of James (1913):

Never were as many men of a decidedly empiricist proclivity in existence as there are at the present day. Our children, one may say, are almost born scientific. But our esteem for facts has not neutralized in us all religiousness. It is itself almost religious. Our scientific temper is devout. Now take a man of this type, and let him be also a philosophic amateur, unwilling to mix hodge-podge system after the fashion of a common layman, and what does he find his situation to be in this blessed year of our Lord 1906? He wants facts; he wants science, but he also wants religion. And being an amateur and not an independent originator in philosophy he naturally looks for guidance to experts and professionals whom he finds already in the field. A very large number of you here present ... are amateurs of just this sort. (pp. 14-15)

Modernity had inherited this acute contrast between the empirical and the religious from the late Middle Ages (Duns Scotus, Ockham) and the Renaissance (Bacon). It became more prominent in the 17th century with science taking the lead and shifting religion to the margins (the subrational sentiments and emotions). 'Reason' sided with the state against faith and the church. It was Kant and Hegel who 'saved' religion by making it part of rationality, yet in doing so actualised a dialectical unity of the two under the leadership of reason. This Modern secular understanding of religion was adopted by many Christians, intimidated by accusations of being 'emotional' and 'unscientific'.

With the advent of Irrationalism in the 19th century (Pragmatism, Heroic Vitalism, Nietzschean Vitalism, and Existentialism), the compromise became a burden (for Christianity), for now religion could be accused of 'rationalism', 'principled dogmatism' et cetera. This is exactly what James does in the table of characteristics (Table 1) and it makes the shift to Irrationalism religiously the best one.

\section{Rationalism versus Irrationalism}

How did Irrationalism make its appearance? The problem lay in the lack of nuance in Modernity's ontological distinctions. It proposed one basic distinction between 'reason' (a vague and encompassing idea) and 'nature' (reduced to the mechanical or the bio-mechanical). A table of the subcategories can help us to develop a brief explanation of the advent of irrationalism (see Table 2).

Not everybody accepted every subcategory in column A or B - different reductionisms occurred regarding both columns. The table categorises the widest spectrum available. In column B the order could be changed: some authors would put 3 in the place of 1 , and shift 2 to 3.

Note the elevated position of the rational sphere: this expresses the ontology of rational human mastery and appropriation. Descartes characterised humankind as masters and owners of nature through science and technology (cf. Descartes 1982:VI). Table 2 shows that, compared to a representative Scholastic philosopher such as Thomas Aquinas, the idea of 'nature' has been shrunk; in Thomas it included 'reason'. In its Modern elevation reason displaced the Medieval supernatural (encompassing faith, grace, church and God). Since its inception Modernity propagated rational control for the sake of human advantage; in fact the 18th century econo-philosopher, Quesnay, defined morally good action as taking advantage through natural science and technology (cf. Venter 2012b:ch. 4.6, A.2).

Hobbes (following Machiavelli) created a ghost that would forever haunt Modernity. He argued that the majority live as mechanical wolves in a perpetual instinctive conflict for power, honour and wealth. It surely is a category mistake

TABLE 2: Rationalism versus Irrationalism subcategories.

\begin{tabular}{|c|c|c|}
\hline \multirow[t]{2}{*}{$\mathrm{Nr}$} & \multicolumn{2}{|c|}{ Categories } \\
\hline & $A \dagger$ & B: \\
\hline 1 & - & Reason (ideal) \\
\hline 2 & - & Understanding (logical) \\
\hline 3 & - & Intuition (synthesising) \\
\hline 4 & Sentiments (taste) & - \\
\hline 5 & Passions and drives (instinctual) & - \\
\hline 6 & Senses & - \\
\hline 7 & Biosphere (physiology) & - \\
\hline 8 & Inorganic & - \\
\hline
\end{tabular}


or an anomaly, for brute animals do not strive for honour and wealth. Modernity had already adopted the principle that humankind has natural roots and a supernatural aim. In Hobbes the roots became a shadowy threat to the survival of both individual and species.

Hobbes's own alternative was to follow reason; that is: to be obedient to the state as reason, to protect wolf against wolf and against power hungry institutions (especially the church hierarchy). As stable alternatives the natural condition versus the totalitarian state were not at ease with one another, but quite in line with the basic framework of the Modern ontology. The answer to such dilemmatic embarrassment lay in the adding of an article to the Modern confession: realityas-human is historical and follows a line of inevitable progress (cf. Venter 1999:18-46).

Columns A and B in Table 2 are then not oppositional alternatives to be kept in balance from side B, but are phases of progress from $\mathrm{A}$ to $\mathrm{B}$. The plebs in Hobbes have a momentous rationality; in their quiet moments they may rationally think about justice and fairness to others; but normally the struggle for power, honour and wealth, and for bare survival over against the more powerful, is the order of the day. This struggle is guided by their natural inclinations, as indicated in column A (see Table 2).

This naturalistic side of Hobbes became the supposed original state, the mentioned shadow following reason as it matures. One finds it in Rousseau, Turgot, Adam Smith, Kant, Hegel. It is the beginning of Turgot's base-superstructure model, later adopted and adapted by Marxism. One can illustrate the faith in progress using a graph-like table.

The horizontal axis of Table 3 (1-7) indicates the direction and development of reality as history. The vertical axis (A$\mathrm{H})$, read column-wise, shows the decline of the influence of 'nature' and the increasing influence of 'reason'. Note that this is the history of a humanised reality; it is still pre-Darwin.

Kant, who clearly accepted the rootedness of the human being in subhuman brutish mechanical animality (Mutmasslicher Anfang der Menschengeschichte; Kant 1975c), does present progress as in Table 3 - that is assuming the presence of a minimal, slumbering rationality in the first 'human' beings. In the Enlightenment representation of this history, subrational nature remains with us, howsoever rational we may become.
Combining Table 2 and Table 3, one has to say that in Table 3 block A1, very little of the rational aspects are in control - in Kant it is by and large only the cooperation of rational choice with the instinctive search for the right food and the sexual urge. Block H7 shows nature still present, though under pressure, but all the aspects of nature noted in Table 2 column A, are still present; this is the Achilles heel of Modern Rationalism.

Assuming that Table 3 column 7 could become a reality in all human beings (and that it had become a reality at least in those who were able to present us with this overview of all history), some very serious problems remained unsolved:

1. How to account for the different supernatural entities taken into account by the Scholastics and displaced by 'reason' in Modernity:

1.1 God? Is He: Non-existent: Part of nature? In reason? On eternal leave?

1.2 Revelation? To be found in: Instinct? Reason? Or is it nothing but myth or projection?

1.3 Faith? An act which is: an Emotion? Rational behaviour? Superstitious?

1.4 Grace: given by: the State as kingdom of God? The General Will?

1.5 Organised religion: institutionalised by: A free church? A State supervised church?

2. Other aspects deemed important, not so easily given a place:

2.1 Morality: A long-term instinct? An emotion? A sentiment? A rational act?

2.2 Art: Instinctual? Rational?

2.3 Practical life: Pure Passion? Quite Rational?

2.4 What does 'rationality' actually mean? [I (JJV) have have found about nine different answers.]

3. A very serious issue would exactly be the relationship between reason-as-lord and nature-as-slave in terms of Table 3 column 7. The majority of humankind would in Table 3 be somewhere between columns 1 and 3 .

3.1 Who are to control the majority - the column 6's and 7's?

3.2 Who are the column 6's and 7's? The Scientists? Technocrats?

La raison de l'état [reason of state]?

3.3 How do we know that the column 6's and 7's will not act according to Table 2 column A - their natural inclinations to care for themselves and instrumentalise others? Who will control the self-appointed intellectual masters? (cf. Kant 1975b)

The different possible answers to these questions each found a defender. Regarding questions 1 and 2: in all too many cases nature became the location and reason (at least in spe [in hope]) the master and owner. In all of Modernity the civil

TABLE 3: Faith in progress.

\begin{tabular}{|c|c|c|c|c|c|c|c|}
\hline $\mathrm{Nr}$ & 1 & 2 & 3 & 4 & 5 & 6 & 7 \\
\hline$A$ & Reason & Reason & Reason & Reason & Reason & Reason & Reason \\
\hline B & Nature & Reason & Reason & Reason & Reason & Reason & Reason \\
\hline$C$ & Nature & Nature & Reason & Reason & Reason & Reason & Reason \\
\hline $\mathrm{D}$ & Nature & Nature & Nature & Reason & Reason & Reason & Reason \\
\hline$E$ & Nature & Nature & Nature & Nature & Reason & Reason & Reason \\
\hline $\mathrm{F}$ & Nature & Nature & Nature & Nature & Nature & Reason & Reason \\
\hline $\mathrm{H}$ & Nature & Nature & Nature & Nature & Nature & Nature & Nature \\
\hline
\end{tabular}

The horizontal axis of the table is represented by the numbers $1-7$ and indicates the direction and development of reality as history, whilst $\mathrm{A}-\mathrm{H}$ represents the vertical axis. Read column-wise it shows the decline of the influence of 'nature' and the increasing influence of 'reason'. 
state represented divine rationality; the head of state thus enjoying divine rights.

The really problematic issues then were those under question 3. Humankind's rootedness in nature implied carrying its 'natural' aspects permanently with it. The issue of external versus internal control of human individuals was dangerously serious. Descartes as monistic interactionist believed that the mechanical could be the causal media of wisdom from one rational subject to another - two purified reasons much too needful of greasy machines. Hobbes chose for external controls and Kant, having seen some results of this, just threw his intellectual hands in the air in the face of 'radical evil'.

\section{Hobbes (1946) put it thus:}

The value, or WORTH of a man, is of all other things, his price; that is to say, so much as would be given for the use of his power: therefore it is not absolute, but a thing dependent on the need and judgment of another ... And as in other things, so in men, not the seller, but the buyer determines the price. ... The public worth of a man, which is the value set on him by the commonwealth, is that which men commonly call DIGNITY. And this value of him by the commonwealth is understood [to be] by offices of command, judicature, public employment; or by names and titles, introduced for distinctions of such value. For he is the worthiest to be a commander ...that is best fitted, with the qualities required to the well discharging of it; and worthiest of riches, that has the qualities most requisite for well using of them: any of the qualities being absent, one may nevertheless be a worthy man, and valuable for something else. Again a man may be worthy of riches, office, and employment, that nevertheless, can plead no right to have it before another; and therefore cannot be said to merit or deserve it. For merit presupposeth a right, and that the thing deserved is due by promise ... (Leviathan $\mathrm{X}$ )

Hobbes (1946) wanted us to believe that:

- the worth of a person is his or her interindividual utility, as judged by the powerful (the demander)

- the dignity of a person is his or her public utility, as assessed by state authorities.

Two requirements for realising such worthiness or dignification are:

1. fitness for the job

2. a pre-existing contract.

But in Hobbes's format, this implies that one human is but $a$ tool for another and all citizens are tools of the state.

Locke (n.d.; TTG, II: 1-10), through his Christian doctrine of the inherent worthiness and thus inalienable rights of humankind and Kant by elevating human reason to the supernatural position, resisted this utilitarian instrumentalising of fellow human beings. It had, however, already been institutionalised in transitional patterns from late feudalism to early capitalism: the international slave trade, exploitative colonialism, exploitation of rural husbandry as well as workers, as the industrial revolution gained momentum. The natural, instinctive care for selfinterest (rational control limited to the momentary actions of the 'impartial spectator') became the struggle for survival in
Darwin and the formalised calculus of pleasure in Bentham (moral philosopher) and the war [sic] to secure it, in his student, Edgeworth (economist).

On the collective side the Hobbesian principle that only the leadership of the collective acts rationally was realised widely by self-appointed intellectual or scientific leaders in different forms of nationalism and socialism: the plebs had to be forced to obey the general will and thus be free (cf. Rousseau 1916:II, vii). Hobbes's promise of protection by civil society, the French revolutionary Condorcet's eschatology of a scientifically morally purified and happy humankind, Kant's promise of perpetual rational peace through a balance of instinctively selfish warring state authorities - all these collapsed in the face of the self-advantaging powerful seeking own utility. Human-beings-in-spe [hoping to be] had but instrumental worthiness for the self-appointed, 'peaceful', rational masters.

\section{Pragmatistic scientism versus Christianity}

During the second half of the 19th century the Christian lovehope-faith trinity had been fully displaced, but intellectuals began to realise that the hope in, and for, reason was futile. Amongst irrationalists a singular, lonely intellectual, Kierkegaard, tried to revive some of the Christian hope ${ }^{2}$. For the rest the compacted nature of Table 3, H7, unfolded into power again, and we see Table 2, column A - brutish nature - return as different currents:

- romanticism chose for the dominance of sentiments and passions

- realism for sense experience

- naturalism for the survival war for basic physiological and instinctive needs

- existentialism for the jump into a dark future to become human

- heroic vitalism for an individual, violent above-human or super-collective

- later positivism for a logic with unstable axioms and rules.

And then there was Pragmatism, pretending to embody all these other currents - yet the focus was on outcomes and output; an Irrationalist utilitarianism ${ }^{3}$. But it was also a

2.1 am thinking here of irrationalist philosophers taken into account in secula textbooks. Depending on the extension of the circumscription of 'Christian', one could of course take thinkers such as the earlier Dilthey and also Schleiermacher into account - even though strongly subjectivistic and rationalistic. In James's day even Hegel's philosophy was considered 'Christian', otherwise a dialectical theology even Hegel's philosophy was considered 'Christian, otherwise a dialectical theology could never have found the acceptance it did. If one is stricter in circumscription, then of course those thinkers not often found in secular textbooks come to mind: in Reformed circles Groen van Prinsterer, Abraham Kuyper and possibly Bavinck; in Catholic circles probably the early Husserl (who considered himself Christian), Blondel and Neo-Thomism amongst others.

3.Utilitarianism is a moral philosophy teaching that moral behaviour is that behaviour which increases utility. In too many cases 'utility' has been equated with increased pleasure and decreased pain - that is 'hedonism'. It has always been difficult to determine whose utility has to be increased: liberal individualists argued that if the individual can take care of increasing my own interests, then utility is increased for everybody. More socially consciousness utilitarians would rather argue that everyone should work for the greatest utility for the greatest number. Utilitarianism as such could fit in with different philosophical attitudes, such as both rationalism and irrationalism. Under rationalism it would argue that one should overcome and ism and strive for rational reflection on what is good for $m e$, or what is good for egoism and strive for rational reflection on what is good for me, or what is good for all - universally. When rationalism was no more fashionable, utilitarianism adopted an irrationalistic heart, called 'pragmatism'. Pragmatism is in fact utilitarianism gone mad. One does no more need to have rational arguments for one's behaviour. A liberal pragmatist would argue: this is ethical, since it works for me. A more socially consciousness pragmatist would be one testing what works for the majority. The universality of rationality has disappeared, one has but to keep on trying - see what works. 
return to 'nature' of a special kind: the natural sub-rational Hobbesian mind. It was the extension of Scientism in its empiricist form; the belief that science was the best approach for the realisation of the Modern agenda.

In the earlier quote from James (1913) he admits to that which has been characteristic of Modernity at least since Descartes; a religious adoration of science and its power, being an ontology of mastery and appropriation in which technical methods have the upper hand (cf. Venter 2012a:ch. 5, J2). This is important: where science and religion are opposed, or state and church, the confrontation eventually shows itself as one between two religions: one transcendentally and the other immanently rooted.

The 'new' 'religion' will - especially when it is science or ideology (the latter mostly an extension of the former) - set itself up as elite, as better, the replacement of the aged, as the gracious one. James presents science as pervasive: every child who loves 'empirical' knowledge, 'facts', is a born 'scientist'. How to reconcile this with the apparently opposite striving for 'religion' is a question which the elite professional Pragmatist philosopher has to answer for you. What answer does the Pragmatist give regarding Christianity?

The Christianity of his days - James (1913:22ff) paints with a broad brush - are of two tender-minded types: the Hegelian pantheist Protestants and the Roman Catholic reserved theists - the one as abstract as the other.

A broad brush, very broad indeed; dripping with dark paint. The dice was loaded to one side: being-crucified upside down, fed to the lions, burnt at the stake, decapitated, jailed for not signing a revolutionary 'confession', going to far-off countries and face disease and death to be among the poor, suffering injustice to be a voice for others, being denied access to public facilities, emancipating the lowest casts - nothing of these could be presented as down-to-earth, factual, empirical tough-mindedness?

The fact that some liberal theologians adopt new intellectual fashions is surely no proof that the majority of Christians follow them? Theology is theory; religion is praxis; and often the cleft between the two becomes quite wide. But James (1913) knows what is really needed:

What you want is a philosophy that will not only exercise your powers of intellectual abstraction but that will make some positive connection with this actual world of finite human lives. You want a system that will combine both things, the scientific loyalty to facts and willingness to take account of them, the spirit of adaptation and accommodation, in short, but also the old confidence in human values and the resultant spontaneity, whether of the religious or of the romantic type. And this is then your dilemma: you find the two parts of your quaesitum hopelessly separated. You find empiricism with inhumanism and irreligion; or else you find a rationalistic philosophy that indeed may call itself religious, but that keeps out of all definite touch with concrete facts and joys and sorrows. (p. 20)

James (1913:28ff) opposes 'intellectual' ideas. But surreptitiously he admits to dogma: empiricism combined with 'inhumanism' is apparently 'wrong'. There is a dogmatic norm here: one has to be both empiricist and humanist. 'What you want ...'. James wants us to have 'spirit' and 'matter'. Christianity fails, being a spiritualistic 'nothing-but'-ter. Religion has had its time, says the materialist. Christ has in two thousand years done nothing for humankind.

\section{Ideology}

William James knows what is good for the new generation. So did Marx. So did Comte. So did Hobbes. Worldviewish prescriptive intellectual elitism - knowing everybody's good cause better than they do themselves - is one of the most prominent characteristics of ideology, especially where outcomes are prescribed whilst one keeps quiet about the means issue. Pragmatism measures effects, outputs and outcomes. Causes, instruments, means, and meanings can be given any sense only in terms of their effects James (1913):

It is astonishing to see how many philosophical disputes collapse into insignificance the moment you subject them to this simple test of tracing a consequence. There can be no difference anywhere that doesn't make a difference elsewhere - no difference in abstract truth that doesn't express itself in a difference in concrete fact and in conduct consequent upon that fact, imposed on somebody, somehow, somewhere, and somewhen. The whole function of philosophy ought to be to find out what definite difference it will make to you and me, at definite instants of our life, if this world-formula or that worldformula be the true one. ... Pragmatism represents a perfectly familiar attitude in philosophy, the empiricist attitude, but it represents it, as it seems to me, both in a more radical and in a less objectionable form than it has ever yet assumed. A pragmatist ... turns away from abstraction and insufficiency, from verbal solutions, from bad a priori reasons, from fixed principles, closed systems, and pretended absolutes and origins. He turns towards concreteness and adequacy, towards facts, towards action and towards power. That means the empiricist temper regnant and the rationalist temper sincerely given up. It means open air and possibilities of nature, as against dogma, artificiality, and the pretence of finality in truth. At the same time it does not stand for any special results. It is a method only. (p. 51)

This quote contains in a nutshell what mature Pragmatism is all about. The characteristics of so-called 'Post-Modernism' are clearly present:

- Intellectual elitism of an ideological kind: every abstract truth must and will make an empirical difference. Note that 'Pragmatism' does not mean having and applying practical experience; it rather means making the empirical world fit one's subjective intentions. It kept the backbone of the Modern ontology of mastery and appropriation.

- No fixed principles, no closed systems, no absolutes and no origins. 'Post-Modernism' has taken its cue from this. There is nothing to hold onto; only an endless muddy pool and we have to muddle through. This is why James, in spite of his self-confidential approach, talks of the Pragmatist mind as 'pessimist'. It is like the joke of the mouse fallen into a huge drum of milk, having to water-tread until the milk becomes cream, then until the cream becomes butter, using the butter as boat to reach the side - very, very, very far away ... And yet, the form does count.

- It is situationistic and eventualistic - prefiguring Foucault's fighting each power event on its own. In James it meant 
bringing 'out of each word its practical cash value' and 'set it at work within the stream of your experience' (James 1913:53). It is focused on the here and now, apparently the short term; Heidegger's staying-where-you-already-are demythologised into empirical results. Within this muddy pool one has to water-tread, looking for that clod of mud to take a little ride on; coming from no beginning and not going anywhere in particular; getting one step 'ahead' each time. One has to ask Nietzsche's Zarathustra where 'ahead' is. It suddenly becomes clear that Feyerabend's revolutionary scientific anarchism or Dadaism was not so very new, though he surely had gone further down the road.

- It is individualistic and even fragmentary. 'Post-Modern' relativistic authors assume endless networks, but are mostly focused on recovering the individual, the fragment, from the network of processes and events. Rationalism insisted that the mind creates universal objects within in its own orbit and that the empirical world - often itself seen as but a mental construct - was subject to these universals as law. James rejects 'bad' a priori reasons; but does this imply that there are good ones, and what would they look like? Given some hidden naturalistic and animalistic views of being human, Hume's issues around induction remained a problem: how come the day-old chicken 'understands' three dimensional space in a way that took geniuses in geometry centuries to discover? In a naturalistic evolutionary context the $a$ priori first became rooted in the sub-rational passions and instincts in Turgot and later (after Darwin) completely absorbed into them, in Freud and clearly in Pragmatism's other grandfather, C.S. Peirce (cf. Peirce 1878).

- And yet it is scholarly worldviewish, analysing worldviews on the basis of their practical effects. What practical, observable effects will make Pragmatism itself true? How does a method without any normative doctrine choose among effects that make it better than for example Rationalism or Christianity?

- The framework of Pragmatism is subjective idea as instrument in an individual mind - whether instinctive or abstract - and its empirical effects.

Presently we do find a kind of social brutalising in a wideranging hedonism, exploitation of human beings for pure material accumulation, a 'civilised' (that is: a technically sophisticated and thus civilly acceptable) disrespect for human life (whether medical or military), all pervading consumerism and skin-deep beautification with no regard to consequences for personal or environmental health.

A professed non-doctrine pretending to be pure method is an attempt to play with means via ends, having no criteria for the goodness of either. Is there a link between present lifestyles and a dominant Pragmatism?

\section{Pragmatism as a worldview and a philosophy}

The quote of James (1913:51; see the previous section on 'Ideology') may help us further: Pragmatism really does not stand for pure method and no doctrine - it 'acts' the opposite of what it preaches. Philosophy has to analyse worldviews ('world-formulas' James calls them), asking the simple question: If worldview A is true, what, empirically observable difference would it make to processes, events and human actions? And if worldview B were to be true? Pragmatism, James suggests, is but a formal philosophy - it is only a method to choose between ideas and doctrines. It does not have its own principles or absolutes:

- 'Only a method'? But doesn't the requirement of having a method already constitute some norm, or principle, or doctrine?

- A method without a content? Doesn't the instruction to evaluate doctrines on the basis of their difference in practical effects constitute a content and a normative one at that?

- And crucially: How to evaluate the different effects? Where do I find the criteria to assess Buddhism versus Christianity - is it an issue of conforming to the effects which $I$ - evaluator - believe a good worldview should deliver? Or in terms of the efficiency of each to deliver on its own promises? If the latter, how then to say which is the most efficient? Are the contents of efficiency in the two cases comparable? And if they are about equally efficient in delivering on their own aims, then what? Or so what?

The Pragmatist turns to concreteness, adequacy, action and power - quite reminiscent of Machiavelli, the French Revolution, Nietzsche and Marx. In intellectual history one of the recurring attitudes is to overstate one's own case and understate the other's, in order to differentiate one's own views from what had gone before. James repeatedly states that Pragmatism is nothing new; it is in fact the oldest philosophy in existence. But of course: it is new in the sense of a critique of the recent past's ineffective philosophies; it is thus better:

- Yet when one reads him carefully, he does not seem to have studied Kant or Hegel intensively, observing the real consequences of their work. For all their cloud-thin abstractions, the practical difference their philosophies could and have made was clear: Kant propagated a league of nations - adopted by Catherine the Great and her successors on the Russian throne - and became the great granddad of the 20th century United Nations. Hegel was the grandfather of Marxism, Stalinism and radical right wing political practices (such as Fascism's systematic framework for the reception of for example Sorel, as executed by Gentile).

- He also did not study Descartes very well, who, for all his aprioristic deductivistic Rationalism, still was the father of technicistic power mongering in terms of the ontology of mastery and appropriation.

- When one talks of proposing a philosophy of concreteness, adequacy, action and power - all the questions posed above return in another form: How to know how much concreteness makes for adequacy? What direction is our action to take? What kind of power and how much of it?

James's selection of outcomes clearly shows that Pragmatism is not merely formal. If one does have any further selection 
criteria, these will fill some books. And if one does not have any criteria, will intellectual life - in its required consequences - then not simply become the brutality of what I personally like to happen, here, now?

Pragmatism stands quite close to the later Auguste Comte's form of Positivism. Since Descartes Modernity had been propagating the idea that if one wanted to be scientific, one had to find inevitable natural laws. If one wanted to control one had to know such laws. In Kant even history is reduced to a natural science for the sake of 'being-scientific' (cf. Kant 1975a:33-34). But his striving for world peace and governance depended completely on his understanding of such laws; the prophet of autonomous freedom surreptitiously required control over humankind. Comte (1957:178-179), however, argued that we are searching for but an approximation of such laws for the sake of mastery and control, a scientific economising for human advantage. He argued in this way, in order to convert the one-eyed specialist and the competitive egoist into a servant of his divinity: Humanity.

A senior Neo-Marxist, Horkheimer (1953), would plead with first year students in Frankfurt always to look beyond their discipline and be sensitive for the suffering of humankind. By then the mastery and appropriation motive had taken its utmost toll - Comte and Nietzsche's above-humans had brought the utmost suffering. During Modernity the idea of evil (conflict, competition) being good or serving the good, progressively transformed itself into a philosophical anthropology of essential mastery-in-unity-with-essentialsuffering. Given the agenda of Modernity, human suffering as essence had to be eliminated by progress to a higher essence; but the 20th century showed the opposite.

During the 20th century (especially after Rorty) a heavy cloud of doubt about the representation, the 'realism' of our pictures of the world, cast a shadow over traditional Modern epistemology. The 20th century sceptics about representation have been a few centuries late: Kant's struggle with the Ding-an-sich [thing-in-itself] had already indicated such doubt. However, as subjectivism grew - Nietzsche and the later Comte being cases in point-activism and power came to overshadow exactitude. Feyerabend noticed this. James (1913) summarised it thus:

When the first mathematical, logical, and natural uniformities, the first laws, were discovered, men were so carried away by the clearness, the beauty and simplification that resulted, that they believed themselves to have deciphered authentically the eternal thoughts of the Almighty. His mind thundered and reverberated in syllogisms ... He thought the archetypes of all things, and devised their variations; and when we rediscover any one of these his wondrous institutions, we seize his mind in a very literal sense. But as the sciences have developed farther, the notion has gained ground that most, perhaps all of our laws are only approximations. The laws themselves, moreover, have grown so numerous that there is no counting them; and so many rival formulations are proposed in all the branches of science that investigators have become accustomed to the notion that no theory is absolutely a transcript of reality, but that any one of them may at some point be useful. Their great use is to summarise old facts and to lead to new ones. They are only a man-made language, a conceptual shorthand ... in which we write our reports of nature; and languages, as is well known, tolerate much choice of expression and many dialects. (pp. 56-57)

The value of theory, even a mathematical theory, like that of any idea whatsoever, does not lie in precision, truth, exactitude, but only in its effects as a tool for power. The cash value idea of theory instrumentalises ideas. 'Theories thus become instruments, not answers to enigmas, in which we can rest' (James 1913:53). Instruments, then, in terms of concretisation, adequation, activism and empowering. Of what and of whom?

Will not the adherents of an idea then also become useful tools for the already powerful? Machiavelli, copying Ancient Roman totalitarianism, presented religion as useful opium for the people - to keep them subdued; one has but to get some control over the pope or the religious leaders. He was copied by Hobbes, Rousseau and Marx. All ideologies instrumentalise ideas for the 'good of everybody', and the 'good for everybody' is shown in the practice of the elites' beliefs (Mao 1968):

The Marxist dialectical philosophy ... emphasizes the dependence of theory on practice, emphasizes that theory is based on practice and in turn serves practice. The truth of any knowledge or theory is determined not by subjective feelings, but by objective results in social practice. Only social practice can be the criterion of truth. (p. 4)

Social praxis as the singular criterion of truth? How short the intellectual distance between James and Mao? James, in summarising the characteristics of Pragmatism, offers us the form of an authoritarian ideology, which allows for any meansserve-ends manipulations and brutalities, to set itself as the 'only' idea that really 'works'. Present-day managerialism is but one form of Pragmatism (authoritarianism, sometimes with a smile). The Pragmatist may then exactly do with religion what Machiavelli propagated: use it as an opiate for the people.

My interpretation is not far removed from that of Groothuis (2013), who refers to Russell's criticism that God in James becomes no more than a 'useful' hypothesis. This apart from the fact that already since Lovejoy's 1908 criticism of James there has been a whole debate about what James could have had in mind by 'meaning' as 'the effects of an idea' and truth as the 'useful effects' - all ambiguities that one may follow up in Rydenfelt (2008), which make it difficult to apply the theory.

\section{James, science and religion}

James started his series of lectures from the perspective of the opposition between religion and empirical science. Einstein, writing at more or less the same time and already strongly influenced by Pragmatism, still adhered to the idea that one could finally solve the puzzle of reality in all its forms and find God's thoughts (cf. Venter, 2012c:41ff). James has moved much further into Irrationalism than Peirce and Einstein; the 
types or religious thinking which other Irrationalists still accepted, he now rejected as tender-minded Rationalism.

Like Machiavelli much earlier, James pretended not to have a problem with religion as such, but with the Rationalist, tender-minded, abstract religion of his time. He quotes from Morrison H. Swift's Human submission (1905), the case of a worker in Cleveland who killed his children and himself in desperation after losing his job (James 1913):

This ... is one of the elemental stupendous facts of this modern world and of this universe. It cannot be glozed over or minimized away by all the treatises on God, and love, and being, helplessly existing in their monumental vacuity. This is one of the simple irreducible elements of this world's life, after millions of years of opportunity and twenty centuries of Christ. It is in the mental world what atoms and sub-atoms are in the physical, primary, indestructible. And what it blazons to man is the imposture of all philosophy which does not see in such events the consummate factor of all conscious experience. These facts invincibly prove religion a nullity. Man will not give religion two thousand centuries or twenty centuries more to try itself and waste human time. Its time is up; its probation has ended; its own record ends it. (p. 31)

James uses this to attack 'rationalism' as an attitude from the empiricist position. Discursively speaking, both James and Swift totally confused rationalist theology with religion itself. The case of the worker here cited surely is of serious concern. However, when one reads Western economic documents from the 16th century onwards, secular capitalistic thinking contributed to the enculturation of the ontology of mastery and appropriation. Some sections of different Christian denominations cooperated with the powers that be, but at least in South African history, missionaries were often quite unpopular with the establishment, for taking the sides of the indigenous people. Wherever the Christian missionaries had gone, real emancipation of ordinary people took place. Traditional social formations have been and still are quite authoritarian and holistic; individuality suffers (cf. further Choi 2000:ch. 6). James, however, like Swift (and the 19th century utopians such as William Godwin) believed that Christianity was 'ineffective'.

Again it is clear that James's comparison was not evenhanded; his selection of oppositional points of comparison was quite arbitrary, and his selection of a critical difference was a twisted, uncritically accepted, traditional opposition.

James's empiricist measurement of Christianity implied yet another hidden normative perspective. When James said that every event made an empirical difference and that philosophy's task was to differentiate between the empirical effects of different worldviews, he approached determinism. However, though evolutionist, he still harboured the Humanist striving for human and humane advantage. Making an empirical difference - effectiveness and efficiency - does not in itself tell us that this or that difference is a good or bad one. Concreteness, adequacy, action and power provide no direction in themselves and from themselves. In spite of his rejection of Rationalism and adoption of unprincipled Irrationalistic empiricism, he adhered to the norms of Humanism: welfare and wellbeing for all, as proposed by the theories of the elite.

Christianity, to be acceptable, had to be purified into a 'humanism' in which the effectiveness of means were to be justified by Humanistic efficiency in mastery and appropriation, especially in individual situations 'on the ground'. However, coming from the tradition of scientism, situational efficiency is not enough. One had to get rid of tensions among one's 'effective' ideas, which means that there is no place for an inconsistent combination of Christianity with Pragmatism; one has to work for consistent effectiveness; immerse oneself completely into the 'paradigm'.

\section{Consistency}

Finding an idea really efficient and effective, it had to be integrated with one's existing ideas. The Comtean approximations of law might not 'work' anymore. Thomas Kuhn, in the Structure of scientific revolutions, understood the implications of this: clashes amongst one's ideas will accumulate up to a heavily anomalous situation; finally a 'scientific' revolution takes place in which the latest successful idea has to make converts, leaving the previous world-formula as a whole behind (cf. Kuhn 1975:ch. 2-4).

James's pretence that one could be a Christian and a Pragmatist could be tested by his theory of integration in order to obtain consistency. Once a theory or a worldview apparently does not produce the required Humanistic results, a new, efficient and effective idea has to be inserted into one's conceptual network. If the new idea really is efficient and effective, then surely the whole body of inherited ideas will have to make way or be changed fundamentally for the sake of consistency. Kuhn, rooted in Pragmatism, lost track of continuity in the history of science. His Pragmatist search for a consistent network of successful ideas forced him in a direction where continuity became invisible, even where explicitly sustained (Einstein denied having been a revolutionary).

Thus James's vision might make Christianity a more efficient 'Humanism', but would it still be recognisable as 'Christian'?

\section{An effective, relative Absolute, in so far forth ...}

James clouded his own understanding of Christianity (or for that matter of religion) in using his own Pragmatist semantics to interpret what 'religion' and 'god' is all about. In his attempt to bring the heavens down to earth, he interprets hedonistic comforting as the practical cash-value of the 'Absolute'. Like Marx, James (1913) was turning Hegel on his head - but is this an explanation of Christianity?:

Now pragmatism, devoted though she be to facts, has no such materialistic bias as ordinary empiricism labors under. More-over, she has no objection whatever to the realising of abstractions, so long as you get about among particulars with their aid and they actually carry you somewhere. Interested in no conclusions but those which our minds and our experiences work out together, she has no a priori prejudices against 
theology. If theological ideas prove to have a value for concrete life, they will be true, for pragmatism, in the sense of being good for so much. For how much more are true, will depend entirely on their relations to the other truths that also have to be acknowledged. As a good Pragmatist, I myself ought to call the Absolute true 'in so far forth' ... But what does true in so far forth mean in this case? To answer, we need only apply the pragmatic method. What do believers in the absolute mean by saying that their belief affords them comfort? They mean that since, in the Absolute finite evil is 'over-ruled' already, we may, therefore, whenever we wish, treat the temporal as if it were potentially the eternal, be sure that we can trust its outcome, and, without sin, dismiss our fear and drop the worry of our finite responsibility. In short, they may mean that we have a right ever and anon to take a moral holiday, to let the world wag in its own way, feeling that its issues are in better hands than ours and are none of our business.... that is his cash-value when he is pragmatically interpreted. If the Absolute means this, and means no more than this, who can possibly deny the truth of it? To deny it would be to insist that men should never relax, and that holidays are never in order. (pp. 73-75)

This sounds much like Sartre a little later, complaining that Christians do not really take responsibility for the world they are creating (Sartre 1970:1-10). Rooted in an idea of truth that says whatever is good for me is true (cf. James 1913:75-76), one cannot but wonder how James's idea of goodness can be reconciled with a Christian idea of such.

Note that James uses the term 'absolute' and not 'Christ' or 'God', submerging concrete Christianity into a Hegelian theological 'Absolute'. He also quietly shifted his terminology: 'theological ideas' (not 'religion') is now his term. Now since he does not distinguish here between theology as an intellectual discipline and religion as a practice, 'theological ideas' is used as a totalitarian blanket cover for ideas inherent in religious practice, yet not present in the Hegelian philosophical theology that his critical discourse targets here. In this context, his presentation of religion is a fargoing misrepresentation.

\section{Religious truth and the belief in God}

What James finds true in religion is that which have an experiential effect on its adherents. This, according to himself, is limited to comfort and relaxation. What about consistency now? James indicated a tension between the belief in an Absolute and his Pragmatist belief that there are no absolutes. Well, he says, I do not have to give up the cash-value of believing in moral holidays by relinquishing this whole metaphysical edifice of Absolutes. One can just find other arguments, more suitable to one's other vital truths and continue on one's way ...

James (1913) insists that Pragmatism does not deny the existence of God. It does, however, propagate a very particular kind of god (even though insisting on having no dogmas or prejudices):

The prince of darkness may be a gentleman, as we are told he is, but whatever the God of earth of heaven is, he can surely be no gentleman. His menial services are needed in the dust of our human trials, even more than his dignity is needed in the empyrean. (p. 72)
Having already presented this idea of God, he later states that Pragmatism, being unprejudiced, will accept both rationalist logic and sense experience, both mysticism and a God who lives in the very dirt of private fact (James 1913):

Her only test of probable truth is what works best in the way of leading us, what fits every part of life best and combines with the collectivity of experience's demands, nothing being omitted. If theological ideas should do this, if the notion of God, in particular, should prove to do it, how could pragmatism possibly deny God's existence? She could see no meaning in treating as 'not true' a notion that was pragmatically so successful. What other kind of truth could there be, for her, than all this agreement with concrete reality? (p. 73)

In a quote above James tells us what kind of a philosophy we need as religious persons. He plays the irreligious, inhumanist empiricism of his times out against the religious, abstract intellectualism of the Rationalists. Table 1, compared directly with Table 2 and Table 3, gives us his prejudices and his rootedness in an older tradition.

One of the most serious prejudices is the hierarchical, oppositional character in terms of which the relationships between column B (rational, civil) and A (the sub-rational) has been expressed. Once one sets foot into this opposition, you find yourself in an intellectual trap between Rationalism and Irrationalism. Modernity has by and large - but not always relegated faith and religion to the sphere of sentiments and/ or emotions. Thus the only empirical cash value that James can find lies on the level of comfort. He then offers us a better deal: a God who is not a gentleman but crawls himself into the dirt of hard, factual life. This is the Pragmatist idea of God; if he is at work, then he surely exists. Or we have to bring him into existence.

Remarkable. One wonders whether James did read the Bible. His picture of this god nears a man from Nazareth. Does not the Bible precisely teach a God who became human and slept out in the open with the poor? Who found his closest followers and future messengers amongst fishermen and rural people in the very outback of Palestine? Who emancipated women (some of suspicious morality) and also despised people (such as treasonous tax collectors)? Who showed solidarity with humankind right into death. And whose followers - sometimes quite negligent - still preach and practice much of what he taught. Not a God of dirty empirical, efficient practice, but of a life of utmost trial and suffering?

When one sublimates the essential traits of a worldviewish tradition into some intellectual doctrine (such as a theology), then the judgemental comparison of 'good' versus 'bad' becomes easy - but can such a comparison sustain assessment for being responsible scholarship?

\section{Context}

There is something interesting, though, in James's attempts to remain a Humanist within the harshness of empiricism. Marx set the example. As was explained above, led by the ideal of 
(natural scientific) certainty, Modernity gradually moved in the direction of a mechanistic naturalism, at least regarding the arche [the primal principle]. Near the beginning was the mechanical wolf. However, in the same vein it was argued that this machine wolf was able, exactly through means of natural law, to solve all of its own problems. For it was quite unlike the natural beings from which it originated - at least some human beings were such and in time the others could become so.

Thence Modernity found itself in a very serious tension: how to show that the arrogant brute calling itself homo sapiens was not only sapiens but in fact at least homo. The recovering of Modernity's lost human god reigns behind the pretence of a pliable, flexible, non-dogmatic, method. Why anyway be concerned with a brute animal that in the eyes of many was only a very complex machine - a brute that brutalises its own kind (for power, honour and wealth)? Some did answer: this one brutal machine could suffer and know its own suffering this made it human. In managing our suffering rationally, we are 'human'.

The only way to really argue the case for humanness was to adopt dialectical logic - opposites come from opposites - as the dialectical materialists (Marxists) did; thus deriving the humane from the brute. Or: to change truth in such a way as to accommodate all pleasures.

In both cases the means-ends relationship becomes amoral. What James expected from religious people is to care for their suffering without caring about the means used. This would mean to adopt the form of ideology. Not all Christians are proud of the outrages of some Crusaders. There is no reason to change course in that direction. Tender-mindedness in the sense of doing the near-at-hand (including caring for one's 'enemies'), rather than blowing a Crusaders trumpet, is what Christianity has been taught to do.

This is not tender-minded in the sense of idealistic weakness, as late-Modern James's early-Modern predecessor, Machiavelli, had already tried to convince his contemporaries.

\section{Those nice impragmatic Christians}

Intellectuals tend to focus on what other intellectuals say or do not say. Present-day philosophy of science provides a case in point. Philosophers of science do not go to laboratories to see what happens; neither do they read enough of scientists' own narratives about their work - especially the lesser known ones on whose shoulders the great ones stood. They tend to read other philosophers of science and develop their own idiolect, not easily accessible for active scientists. I have indicated above that James confused theological doctrine with religious practice. The theology of the 19th century took the direction of deist or pantheist abstract Rationalism and this is what James attacks as 'tender-minded' Christianity.

Christians who have the strength to suffer are in fact people of action and determination. They are prepared to serve in circumstances of suffering; to suffer with those who suffer. Strength in suffering is not an end in itself; martyrdom is not something to be sought after; it is imposed by those opposed to fulfilment of calling. As with all worldviews, Christianity has its deviants. I do not believe it has more deviants than any other belief system. Yet present-day research indicates that in South Africa, charismatic Christians, sometimes ridiculed for the literal use of the Bible and their sentimentalism, have been doing and spending much more for the sake of the poor than the pretentious left wing government.

One could also say that James was a late-ideologue. I do not use the prefix 'post', for it would be a denial of historical continuity, which is still present in and after any shift, howsoever radical. 'Post-Modernism' is rather more early Modern than after-Modern. James hung unto the 'form' of ideology - end-driven strategic thinking without ado. Like the 'Post-Modernists' - of which James may be a grandpa - James shares the ideological form with the proto-Modern, Machiavelli. The latter, followed by Hobbes, Rousseau, Voltaire and all of the French Revolution (and also Kant to a certain extent), adopted the Ancient pagan tribalist view of the state, impatient with people who would not serve their divinity. Or one could also say that James was a postRationalist carrying (or being burdened by) suppressed Modern beliefs in the continuity of Western tradition. These include:

- A trust in method that supposedly would guarantee both the correct way and the finding of the good life.

- A 'denigration' of Christian voluntary kindness, given its practical inefficiency and ineffectiveness, coming all the way from Machiavelli via the state absolutists and the utopians up to tough-minded Pragmatism.

- A strong belief in a strictly 'empirical scientific' approach, although James, given his Pragmatist suppression of dogma, was a bit more playful in experimenting and observation than his Rationalist predecessors.

- A deep conviction that conceptual work had to find its real fulfilment in practical activity and change, from a subjectivist pragmatist perspective, according to which the world has somehow to be force-fitted to our ideas, playing around with different ideas until we find the world's soft underbelly from where to force it to play the game according to our rules.

- A situationist (local) focus: doctrines have to work in specific situations and to a certain extent the situation, being problematic, was awarded a prescriptive role, a softened late-positivist scientism where laws, as expressed in rules, were supposedly but approximations validated by the level of their expected practical effects. (From the viewpoint of formal logic, this is the error of affirming the consequent.)

Really important from the perspective of his handling of the issue of religion, I believe the above summary of the traits of ideology-at-work shows its presence in James's work.

In the case of James the norms for his selection of aims and especially the Pragmatist means remain quite hidden. 
However, in his criticism of religion it is clear that they are in the extension of Modernity's striving for control for the sake of human advantage from a naturalistic perspective. In terms of these far-away ends James sets up his polar table to distinguish between the tender-minded and the toughminded and offers the Christians a conversion via Pragmatist purification, in order to find a god that has naturalistic, humanitarian effects. Pragmatistic methodistic purification is the shoes that should make the Christians' idea-legs walk in the mud of human suffering. Given his scientistic blinkers, James overlooked the pragmatic value of Rationalism and the practical value of the Christian faith, classifying the latter in terms of the former, misunderstanding both as weak and impracticable. Surely Christianity is a very difficult faithpractice: it is not simple or easy to love one's enemy, to be obedient to inimical authorities, to forgive and try again. But what kind of hope does an empty method - empty efficiency of means, that will make the means the real ends - with a hidden hedonistic doctrine, offer?

In contrast, Christians with a strong philosophical profile, such as Blaise Pascal (1919:409) and Gabriel Marcel (cf. Venter 2002) view such 'weakness' - that is non-EGO-ist 'weakness' over against the other - as exactly the nucleus of the dignity of the human being.

\section{Acknowledgements}

The author declares that he has no financial or personal relationship(s) which may have inappropriately influenced him in writing this article.

\section{References}

Carnap, R., 1932, 'Die physikalische Sprache als Universalprache der Wissenschaft', Erkenntnis II, 1932, 432-465.

Choi, Y.J., 2002, Dialogue and antithesis: A philosophical study on the significance of Herman Dooyeweerd's transcendental critique, Hermit Kingdom Press, Philadelphia.

Comte, A., 1957, Catechisme positiviste ou sommaire exposition de la religion universelle en treize entretiens systematiques, Temple de I'Humanité, Rio de Janeiro. (Reproduction de l'edition apostolique par Jorge Lagarrigue 1891).

Descartes, R., 1982, Discours de la méthode, Paris, Hatier.

Feyerabend, P.K., 1975, Against method. Outline of an anarchic theory of knowledge, London, Verso. PMCid:1681802

Goudzwaard, B., 1981, Genoodzaakt goed te wezen; over de Christelijke hoop in een bezeten wereld, Kok, Kampen.
Groothuis, D., 2013, 'Some problems with Pragmatism', in bethinking.org, viewed 20 May 2013, from http://www.bethinking.org/spirituality/advanced/someproblems-with-pragmatism.htm

Hobbes, T., 1946, Leviathan, or the matter, form and power of a commonwealth, ecclesiastical and civil, Blackwell, Oxford.

Horkheimer, M., 1953, Akademisches Studium, Begriff der Bildung, Fragen des Hochschulunterrichts. Gegenwärtige Probleme der Universität, Klostermann, Frankfurt. (Frankfürter Universitätsreden, N F Heft 8).

James, W., 1913, Pragmatism: A new name for old ways of thinking. Popular lectures on philosophy by William James, Longmans Green, London.

Kant, I., 1975a, 'Idee zu einer allgemeinen Geschichte in weltbürgerlicher Absicht', in $H$. Reiss (ed.), Immanuel Kant Werke in Zehn Bänden, Bd. 9, Schrifen zu Anthropologie, Geschichtsphilosophie, Politik und Pädagogik, pp. 33-50, Erster Teil, Wissenschaftliche Buchgeselschaft, Darmstadt.

Kant, I., 1975b, 'Beantwortung der Frage: Was ist Aufklärung?', in H. Reiss (ed.) Immanuel Kant Werke in Zehn Bänden, Bd. 9. Schriften zu Anthropologie, Geschichtsphilosophie, Politik und Pädagogik, pp. 53-61, Erster Teil, Wissenschaftliche Buchgeselschaf, Darmstadt.

Kant, I., 1975c, 'Mutmasslicher Anfang der Menschengeschichte', in H. Reiss (ed.), Immanuel Kant Werke in Zehn Bänden, Bd. 9. Schristen zu Anthropologie, Geschichtsphilosophie, Politik und Pädagogik, pp. 85-102, Erster Teil, Wissenschaftliche Buchgeselschaft, Darmstadt.

Kuhn, T.S., 1975, The structure of scientific revolutions, University of Chicago Press, Chicago/London.

Latour, B., 1993, We have never been modern, transl. C. Porter, Harvard University Press, Cambridge. PMCid:206779

Locke, J. n.d., The two treatises of civil government, London/New York, Dent/Dutton. (Everyman's library, 751).

Mao Tse-Tung, 1968, Four essays on philosophy, Foreign Languages Press, Peking.

Marcuse, H., 1966, One dimensional man. Studies in the ideology of advanced industrial society, Beacon Press, Boston.

Pascal, B., 1919, Collection Gallia: Pensées, vol. 4, J.M. Dent, Paris.

Peirce, C.S., 1878, 'The order of nature', Popular Science Monthly, June (1), 201-213.

Popper, K.R., 1969, Conjectures and refutations: The growth of scientific knowledge, Routledge \& K. Paul, London.

Rousseau, J-J., 1916, The Social Contract and the Discourses, transl. G.D.H. Cole, Dutton, Dent.

Rydenfelt, H., 2008, 'Meaning and pragmatism - James on the practical consequences of belief', in Nordic Pragmatism Network, viewed n.d., from http://nordprag.org/ papers/Rydenfelt\%20-\%20Meaning\%20and\%20Pragmatism.pdf

Sartre, J.P., [1848] 1970, L' Existentialisme est un humanisme, Editions Nagel, Paris.

Venter, J.J., 1994, 'Reformational university basis in operation', Orientation: International circular of the Potchefstroom University for Christian Higher Education, Jan-Dec, 260-295.

Venter, J.J., 1995, 'Ontologie, representasie en metode (Hume, Hegel, Heidegger)', in H.M. Viljoen (red.), Metodologie en representasie, bl. 129-229, Human Sciences Research Council, Pretoria.

Venter, J.J., 1999, “'Modernity”: The historical ontology', Acta Academica 31(2), $18-46$.

Venter, J.J., 2002, 'Human dignity in weakness - Gabriel Marcel's conception of human dignity (versus Mussolini and Skinner)', Analecta Husserliana 74(1), 351-372.

Venter, J.J., 2012a, Meet a personae called 'Nature'. Early Modern conceptions of natural law. Natural, all too SUPER-natural, Question Mark, Potchefstroom.

Venter, J.J., 2012b, Nature as person-god, humankind as thing-god; the law as omnigod: Headstand Humanism from Physio-Cracy to Positivism, Question Mark, Potchefstroom.

Venter, J.J., 2012c, 'Einstein's thought', in J.J. Venter (ed.), Einstein: Meetkunde en ervaring/Geometry and experience, pp. 2-79, Question Mark, Potchefstroom.

Voltaire, 1765, s.v. 'bien', in Dictionnaire philosophique, portatif, viewed n.d., from http://www.archive.org/details/dictionnairephi03voltgoog 